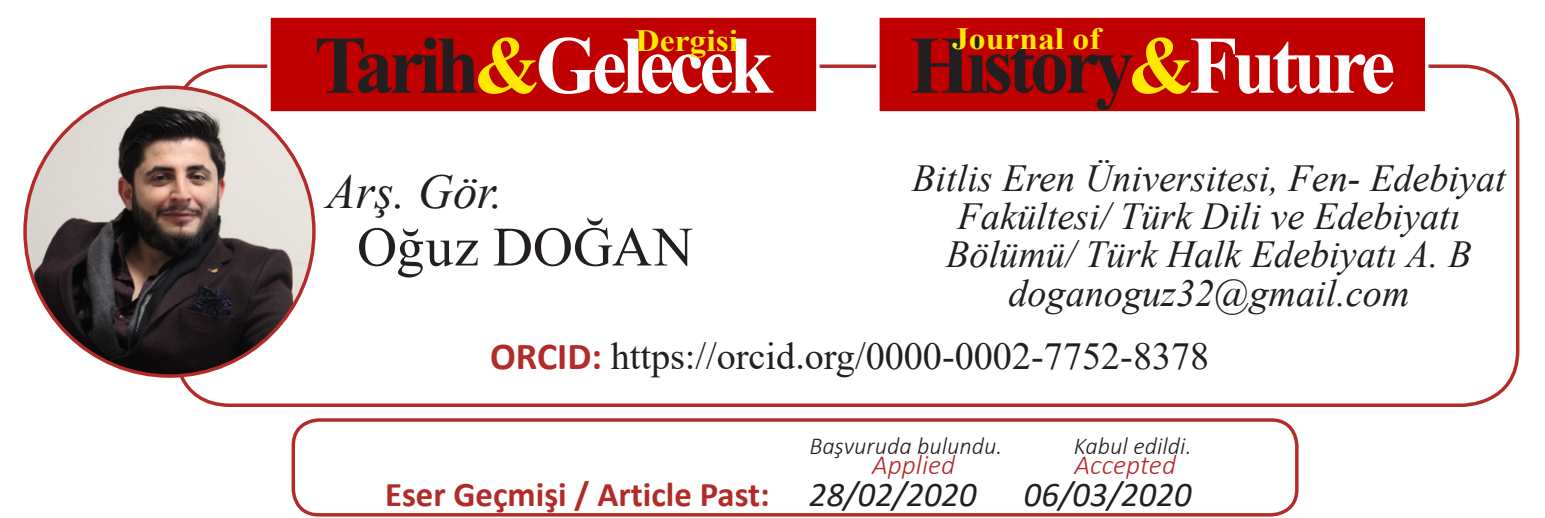

Araştırma Makalesi

DOI: http://dx.doi.org/10.21551/jhf.696009

Research Paper

Orjinal Makale / Orginal Paper

\title{
Bitlis Efsanelerinde Su Kültünün Yansımaları
}

\section{Öz}

\author{
Reflections of the Water Cult in the Legends of Bitlis
}

Doğanın dört temel unsurundan biri olan su, canlı yaşamının devam etmesi için oldukça önemlidir. Yaşamın her alanında ihtiyaç duyulması ve ölümsüzlügü simgelemesi unsurun farkl inançlarda, kültürlerde ve dinlerde sıklıkla işlenmesini olağan hale getirmişstir. Özellikle eski Türk halklarının inancı olan Șamanizm, doğada bulunan her şeyin bir ruhu olduğuna söylemektedir. Şamanizm 'de ruh taşıdığına inanılan ve saygl duyulması gereken başat unsur ise sudur. Suya gösterilen bu saygl geçmişten günümüze kadar gelinen süreç içerisinde halk anlatmalarına farklı şekillerde yansımıştır.

Sözlü kültürün varliğını canlı bir şekilde devam ettirdiği yerlerden olan Bitlis ve ilçelerinde derlenen efsanelere bakıldığında çeşitli kültlerin yansıması olarak degerlendirilebilecek durumlar karşımıza çıkmaktır. Yörenin coğrafi şartlardan ötürü zengin su kaynaklarına sahip olması unsurla alakalı inanışların ve efsanelerin ortaya çıkmasını sağlamıştır. Efsanelerin içerisinde bulunan su kültünün yansımaları doğanın korunmasını için insanlara mitik çağrılarda bulunmaktadır. Bölgede suların merkezinde olduğu anlatılarla aslında yaşamın olağan dengesi korunmaya çalışllmaktadır. Cü̈nkü yaşamın kaynağl olarak görülen suya zarar veren kişileri efsane içerisinde verilen olağanüstü cezalarla toplumsal vicdanda cezalandırllmaktadır. Böylelikle mitik düsünce gizil şekilde uyarılarda bulunarak doğanın korunmast ve saygl gösterilmesini insanlara sezdirmektedir. Bu bağlamda yöre efsanelerin yapısındaki su kültü yansımaları belirlenerek tür içinde gizlenen kodlar okunmaya ve toplumsal yarara sunulmaya çalışılmıştır.

Anahtar Kelimeler: Su, Kült, Bitlis efsaneleri, Kültür, Şamanizm

\section{Abstract}

Water, which is one of the four basic elements of nature, is very important for the survival of life. The need for all areas of life and symbolizing immortality made it common for the element to be frequently processed in different beliefs, cultures and religions. Shamanism, especially the belief of the old Turkish peoples, says that everything in nature has a soul. The main element that is believed to have a soul in shamanism and that must be respected is water. This respect for water has been reflected in different ways in public narratives in the process from past to present.

When we look at the legends compiled in Bitlis and its districts, where the verbal culture continues to exist live, we encounter situations that can be considered as the reflection of various cults. The region's rich water resources due to geographical conditions led to the emergence of beliefs and legends about the element. The reflections of the water cult in the legends call mythical people to protect nature. With the narratives that are in the center of the waters in the region, the usual balance of life is tried to be preserved. Because the people who harm the water, which is seen as the source of life, are punished in social conscience with extraordinary punishments given in the legend. Thus, mythical thought makes secret warnings and makes people feel that the protection and respect of nature are respected. In this context, water cult reflections in the structure of local legends were determined and the codes hidden in the species were tried to be read and presented to the social good.

Keywords: Water, Cult, Bitlis legends, Culture, Shamanism

ATIF: DOĞAN Oğuz, "Bitlis Efsanelerinde Su Kültünün Yansımaları", Tarih ve Gelecek Dergisi, 6/1 (Mart 2020), s. (149-157) 


\section{Giriş}

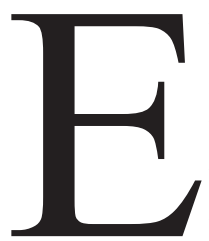

vrende bulunan tüm nesnelerin ana maddesi olarak kabul edilen dört temel unsurdan (hava, ateş, su, toprak) birisi sudur. İnsan vücudunun büyük bir oranını oluşturan su yaşam boyunca ihtiyaç duyulan ve aranılan unsur olmuştur. Nesnelerin varlıklarını borçlu olduğu su, dünya toplumlarındaki yaratılış mitlerinde de bu misyonuyla yer edinmiştir. Eliade, ölümsüzlüğün kaynağı olan suyun, bereket ve yaşam olasılığının sonsuzluğunu simgelediğini söylemektedir. ${ }^{1}$ Suyun ölümsüzlük ve sonsuzluk simgesi olarak görülmesinin kaynağı ise mitik varoluşun yansımaları olarak değerlendirilebilir. Çünkü "Suyun kutsallı̆̆ mikro-kozmosun, tıpk makro-kozmos gibi su ile başlayıp, su ile sona ermesine dayalıdır." Mitik düşünce açısından varoluşun kaynağı olarak görülen su kapsadığı yer bakımından da oluşumun varlık alanı olarak kabul edilmiştir. Su özünde varoluşu sağladığı içinde kutsallığın başlangıcı ve sonu olarak ele alınmaktadır.

Ana rahmi insanoğlunun bir noktadan başlayarak var olmaya başladığı ilk eşiktir. Fiziksel manada çocuk fetüsteki sıvının içerisinde büyüyerek oluşumunu tamamlar. Suyun varlık alanı bu açıdan da kolektif bilinçdışında yerini almaktadır. Diğer toplumlarda olduğu gibi Türk toplumunda da su varoluşun temel kaynağı olarak görülmektedir. "Yer- su" olarak bilinen kült inancı çerçevesinde ruh taşıdığına inanılan unsurların başında suya yer verilmesi mitik varoluşa işaret etmektedir. "Türk yaratılış mitinde kozmos, sudan türetilmiştir, başka bir deyişle yaratılışın başlangıç nüvesi sudur. Bütün canlılarda sudan yaratılmıştır"3. Kozmosta var olan her şeyin tözünde suyun olduğu düşüncesi Türk kozmogonisini böylece şekillendirmişt ir.

Türk mitoloji sisteminde iye sahibi olduğuna inanılan önemli kutsal su ve su kaynakları bulunmaktadır. Nitekim Altay Türkleri, Başkurtlar ve Azerbaycan Türkleri arasında su iyesi inanışı oldukça güçlüdür. "Azerbaycan Türkleri'nin koruyucu ruhlar olan sahiplerle ilgili inançlarına göre "su sahibi" bu sahiplerin en üstü sanılır. Onun için, sabahlarl suya gidildiğinde, "su sahibi"ne selam verilmelidir. Suya pis su dökmek ise yasaktır". ${ }^{4}$ Sular toplum bilincinde ruh taşıan ve varlığın özünü teşkil eden yerler olması nedeniyle çevrelerinde kutsama törenleri yapılmaktadır. Suyun insan psikolojisi üzerindeki olumlu etkisi, onu eski Türk topluluklarında hastalıkların tedavisinde kullanılan başat unsur haline getirmiştir. Hayat vermesi, temizlemesi ve arındırması suyun iyi ruhların merkezi olduğu düşüncesini ortaya çıkarmıştır. Bundan dolayı suya karşı saygı geliştirilerek su kaynakları korunmaya çalışılmıştır. Toplumun bilinçdışında yer alan iyi ruh algısı suya dua edilmesini de beraberinde getirmiştir. Altayların geleneksel dünya görüşü çerçevesinde doğa ve doğa unsurlarına çeşitli vesilelerle dualar (alkışlar)edilir. Bu bağlamda yaratılan her şey ruh taşıdığından ona saygı gösterilir. Söz konusu ruhların varlığına istinaden doğa unsurlarının etrafinda uygulanan geleneksel yasaklar bulunmaktadır. Belli su kaynaklarının başında gürültü yapılmaz ve sular kirletilmez. ${ }^{5}$ Suyun ruhuna dua edilmesinin ve kutsanmasının dişında ayrıca ona kurbanlar

1 Mircea, Eliade Okültizm, Büyücülük ve Kültürel Modalar, (çev. Cem Soydemir), Ankara, Doğu Batı Yayınlar1, 2016, s. 146.

2 Fuzuli Bayat, Türk Mitolojik Sistemi II(Kutsal Dişi- Mitolojik Ana - İyeler ve Demonoloji), Ankara, Ötüken Yayınlar1, 2016, s.248.

3 Fuzuli Bayat, Türk Mitolojik Sistemi II (Kutsal Dişi- Mitolojik Ana - İyeler ve Demonoloji), Ankara, Ötüken Yayınları, 2016, s.248.

4 Rövşen Alizade (2012); Türk Kültüründe Kültler, İstanbul, İstanbul Aydın Üniversitesi Yayınları, 2012, s. 62 .

5 G. Ahmet Can, Asena, Altay Bilik, İstanbul, Pan Yayıncılık, 2011, s.53. 
da adanmaktadır. Yakutlar çayın üzerine astıkları "taig” adını verdikleri kurban törenlerini düzenlerler. Hakaslar da su iyesinin şerefine "sug" adını verdikleri kurban ritüellerini gerçekleştirmektedirler. ${ }^{6}$ Türk halklarının yaşadığı yerlerde su iyesi inanışının izlerini insanların günlük yaşamları içerisinde gerçekleştirdiği ritüellerde görmek mümkündür.

Mitik manada varoluşun kaynağı olarak düşünülen suyun yansımaları Türk toplumuna ait destanlarda, hikâyelerde ve sözlü kültür ürünlerinin muhtevasında kendisini yoğun bir şekilde göstermektedir. Dede Korkut Hikâyelerinde su unsuru yaratılış mitindeki özellikleriyle ortaya çıkmaktadır. "Eski mitlerin öncül kahramanı Korkut Ata'nın "suya ecel gelmez” düşüncesi ile ölümsüz bir yer ararken su üzerinde durması kozmogonik eylemin önemli rolünü gösteren mitik ögelerden biridir." ’ Oğuz Kağan Destanı, suyun mitik değerlerini içerisinde barındıran ürünlerden bir diğeridir. Destan kahramanı Oğuz Kağan'ın eşi dişil karaktere sahip durgun su olan gölün ortasındaki ağacın oyuğuna inmiştir. Kahramanın çocuklarından olan Denizhan da destan içerisinde suyun sembol kişisi olarak verilmiştir. Aynı zamanda kahramanın eşi gökten düşen 1şıktan varlık bulmuş kutsal kaynaklı bir ruh olarak da yorumlanabilir. Ağaç oyuğuna inen ruh ile "yer- su" ruhları kabul edilen unsurların ortaya çıkmasını sağlamıştır. Bu açıdan bakıldığında destan içinde kozmosun varoluşu, suyun varlık alanı olan dişil durgun suda gerçekleşmiştir.

Su aynı zamanda yeniden var olmanın ve yenilenmenin kaynağıdır. Özellikle ilahi dinlerin tamamında su temizlenmenin, arınmanın ve böylece yenilenmenin unsuru olarak kullanılmaktadır. Hristiyan inancı gereğince yapılan vaftiz töreninde suya batırılan bireyin günahlarından temizlendiğine ve yeniden doğduğuna inanılmaktadır. İslamiyet'te ise gün içerisinde beş defa eda edilmesi gereken ve ilahi buyruklarla zorunlu kılınan namaz ibadetinden önce suyla abdest alınması gerekmektedir. Alınan abdest ile yenilenme, tazelenme ve arınma sağlandığına inanılır. Bu şart gerçekleştirildikten sonra namaz ibadeti yerine getirilir. Bunun dışında suyun İslamiyet açısından değeri Hz. Peygamber'e dayandırılan "Temizlik imandandır" hadisiyle de ortaya konulmaya çalışılmaktadır. Söz konusu hadisin kaynağında fiziksel temizliğin yanında ruhsal açıdan da bir temizliğe dikkat çekilmektedir. Ayrıca İslam toplumları açısından kutsal kabul edilen Zemzem suyu bellek açısından oldukça önemli bir yere sahiptir. İslamiyet unsura yüklediği kutsiyetle ilişkili olarak suyun kirletilmesini ve israf edilmesini uygun görmeyerek ona verdiği değeri ortaya koymaktadır.

Yaşam ve ölümü varlığında birleştiren ab- 1 hayat, halk kültürü açısından önemli olan ve sözlü kültür ürünlerinde sıklıkla adı geçen sudur. Ölümsüzlüğün ilacı olarak anlatıların içerisinde yer alan ab- 1 hayat, hayat suyu, bengisu gibi diğer adlarıyla da bilinmektedir. Halk anlatılardan hareketle suyun Hz. Süleyman, Lokman Hekim, Hz. Hızır ve İlyas, Köroğlu vs. gibi şahsiyetler tarafından arandığına rivayet edilmektedir. Sembolik manada ab- 1 hayat, kahramanı maceraya çağıran mitik bir öğedir. Çağrının temelinde ise ölümsüz olma arzusu içerisinde olan insanoğlunun ontolojik dürtüleri yatmaktadır. Anadolu'da halk inanışlarına göre Hz. Hızır sudan içip ölümsüzlüğü bulan kişidir. Aynı zamanda suyla yıkanıp görünmez olmuştur. Bu nedenlerden ötürü Hz. Hızır kültü Anadolu insanları arasında canlılığını koruyarak sürdürmektedir. Ab- 1 hayat suyu düşüncesi etrafında farklı bölgelerdeki sulara kutsallık yüklenmiştir.

Bitlis ve çevresi geçmişten günümüze kadar gelinen süreç içerisinde farklı kültürlere ve medeniyetlere ev sahipliği yapmıştır. Bu durum ise bölge insanını diğer topluluklarla kültürel etkileşime açık bir yer haline gelmiştir. Söz konusu durumdan dolayı bölgede farklı şahsiyetlerle, mekanlarla, yapılarla, ve coğrafi şekillerle alakalı anlatılan efsanelerle karşılaşılmasını olağan hale

6 Fuzuli Bayat, Türk Mitolojik Sistemi II (Kutsal Dişi- Mitolojik Ana - İyeler ve Demonoloji), Ankara, Ötüken Yayınları, 2016, s.249.

7 Rövşen Alizade, Türk Kültüründe Kültler, İstanbul, İstanbul Aydın Üniversitesi Yayınları, 2012, s. 59. 
getirmiştir. Nitekim Bitlis efsaneleri konu çeşitliliği açısından oldukça zengindir. Bu bağlamda yöre insanın yaşam anlayışııın hakkında bilgi vermesi amacıyla Bitlis efsanelerinin muhtevasında barındırdığı sembol, kült ve imajların çözümlenmesi gerekmektedir.

\section{Bitlis Efsanelerinde Su Kültünün Yansımaları}

Hayatın birçok alanında olduğu gibi halk kültürü ürünlerinde de su kültü anlayışının devamı niteliğindeki olaylar bulunmaktadır. Derlenen efsanelere bakıldığında kolektif bilinçdışında var olan suyun kutsallığ düşüncesi metinlerde kendisini mitik döneme paralel olarak ortaya koymaktadır. Mecnun Bulağ ${ }^{8}$ adlı efsaneye göre Bitlis' in Ahlat ilçesinde dört yüz yıllık bir ağaç bulunmaktadır. Merdiven gibi çıkılabilen ağaç oldukça büyüktür. Günün birinde ağacın yanından Leyla ile Mecnun geçer ve burada su olmadığını görünce üzülürler. Bunun üzerine Mecnun elini duvara koyar ve oradan su çıkar. Mecnun suyu eliyle suyu Leyla'ya içirir. Çıkan suya olayın kahramanından dolayı Mecnun bulağı denilmeye başlanır. Su mitolojilerde başlangıcın ve hayatın ana unsuru olarak kabul edilmektedir. Derlenen efsanede temel sorun devasa büyüklükteki yaşlı ağacın yanında suyun olmamasıdır. "Hayatın sürekli ve geri dönüşümsüz akışını, su imgesiyle bütünleştirerek kolektif bilinçaltına yerleştiren insan, zamanın görklü ve dinamik akışında süratli bir var olma mücadelesi verir. Bu var oluş mücadelesinde suyun "akar", ya da "akıntıll” olmasl, devamlılı̆ı̆n yani canlılığın "kuru”, "bulanık” ve "cllız” olması da cansızlığın, hastalığın ve ölümün bir göstergesi sayllmıştır." "Efsane kahramanı ağacın yanına geldiğinde suyun olmadığını görür ve üzülür. Elini vurduğu yerden suyun akması insanın var olma mücadelesi olarak olay içerisinde karşımıza çıkmaktadır. Ağaç kültü ile bağlantılı olarak anlatılan efsanede susuz ve kurak olan yer, hayat belirtilerinin olmadığı kapalı mekândır. Efsane kahramanı elini duvara koyarak, kapalı olan mekânı ortadan kaldırarak hayatın simgesi olan suyun ortaya çıkmasını sağlar. Böylece yaşamın habercisi olan su kapalı olan mekânı açık duruma getirir. Efsane kahramanı Mecnun'un akan sudan elleriyle Leyla'ya içirmesi ise suyun hayat vericiliğine işaret olarak yorumlanabilir. Çünkü merkezde yer alan ağaç, su unsurunun eksikliğinden dolayı cansızlık ve ölümü yansıtmaktadır. Bu durumla karşılaşan Leyla ve Mecnun söz konusu durum karşısında üzülmüşlerdir. Olay içerisinde suyun ortaya çıkması ve erkek kahramanın eliyle kadına su vermesi hayatın tekrar ortaya çıkmasını sağlamıştır. Ortaya çıkan su ağacın özelliğini değiştirerek onun merkezi hayat ağacı olmasını sağlamıştır.

Seydo Bulağ1 ${ }^{10}$ efsanesinde kahraman âşık olduktan sonra amansız bir hastalığa yakalanır. Gördüğü rüyada kendisine şifa olacak bitki ve bulunduğu yer gösterilir. Seydo devasını bulmak için rüyasında belirtilen yere doğru gider. Gittiği yerde bitkiyi bulan Seydo onu koparacağ 1 sırada karşısına yaşlı bir adam çıkar. Yaşı ıdam, kahramana bitkiyi koparmamasını öğ̈̈tler. Seydo kendisine yapılan çağrıya yanıt vermez ve bitkiyi koparıp sağlığına kavuştuğunu düşünür. Uyarıya rağmen koparılan bitkinin kökünden su çıkar. Fakat aradan belli bir zaman geçtikten sonra kahraman kendisine yapılan gizil çağrıya yanıt vermediğinden ölür. Düşün sistemi içerisinde su bazen gizil ve evrensel güçlerin toplamı olarak varlığını gösterir. Çünkü bütün varoluş olanaklarının hazinesi olan su, her biçime ve her oluşuma katkı sağlamaktadır." Anlatılan efsanede gizil güçlerin uyarısına rağmen koparılan bitkinin kökünde çıkan su sembolik manada oldukça önemlidir. Bitki dikey olarak gökyüzüne doğru yükselmekte ve içerisinde yaşamın gizil güçlerini barındırmaktadır. Bu dikey boyut aynı zamanda eril özellikler taşımaktadır. Koparılan bitki ortadan kaldırılan ve tahrip edilen

8 Kaynak Kişi, Ceylan, Göktürk, 1992, Lise Mezunu, Ev Hanımı, Ahlat.

9 Ramazan, Korkmaz, "Dede Korkut Hikâyelerindeki Su Kültünün Mitik Yorumu” Türk Kültürü, 1998, s. 92.

10 Barış, Kızıltoprak, Bitlis Masal ve Efsaneleri, Bitirme Tezi, Yüzüncü Y11 Üniversitesi, Van, 1998.

11 Ramazan, Korkmaz, "Dede Korkut Hikâyelerindeki Su Kültünün Mitik Yorumu” Türk Kültürü, 1998, s. 94. 
uyumun karşılığıdır. Yatay boyutta ise bitki koparıldıktan sonra ortaya çıkan su dişil karakterdedir. Dişil unsur olan su gizil güçler sayesinde ortadan kaldırılan uyumun tekrardan sağlanmasına imkân vermiştir. Su yenileme, doğurganlık ve tekrardan oluşturma özelliğiyle doğanın olağan işleyişini tekrar yerine getirmesini sağlamıştır. Bitlis' in Sekiz Ağustos mahallesinde günümüzde de bulunan su insanların şifa beklentisiyle ziyaret ettiği bölgenin önemli yerlerindendir. İnsanların anlatılan efsaneye bağlı olarak suyu şifalı olarak görmesi unsura yüklenen misyonun karş1lı̆̆ıdır. "Bunun için geçmişin bilgisine ve tecrübelerine insan, zaman boyutunda iletken ve yansitıcı özellikleriyle su imgesinde ulaşacaktır. "12 Suyun belirli zamanlarda insanlar tarafindan ziyaret edilmesi ve şifa için kullanılması unsurun geçmişi günümüze iletmesinden kaynaklanmaktadır. Efsane kahramanın yapılan çağrılara yanıt vermeyip karşılaştığı son, gelecekteki insanlara bir tecrübe aktarımı olarak yansımıştır. Bu olayların taşıyıcısı ve koruyucusu ise su unsuru olmuştur.

Su imgesinin sembolik değeriyle karşımıza çıktığı efsanelerinden birisi de Zeydan ve Şorki ${ }^{13}$ adlı metindir. Rivayete göre eskiden Bitlis'in Zerdan mahallesinde oldukça zengin fakat zenginliği ölçüsünde cimri olan insanlar yaşamaktadır. Günün birinde mahalleye fakir bir aile taşınır. Ailenin çocuğu hastalanır ve baba oğlunun sağlığına kavuşması için mahalledeki tüm evleri kapı kapı gezer. Kimse fakir adama yardım etmez. Efsane kahramanının oğlu yoksulluktan dolayı ölür. Bu ölüm adamın mahalle insanlarına öfkelenmesine neden olur. İntikam duygusuyla yaşayan adam günün birinde yerden çıkan ve içimi oldukça lezzetli olan bir suyla karşılaşır. İçen insanların bağımlısı olduğu su sayesinde zenginler adama ihtiyaç duymaya başlar. İntikam arzuları içinde olan kahraman suya zehir atarak bütün mahalleyi zehirler ve onları öldürür. Bu suyun kalıntıları sonradan Zeydan olarak değişen mahallede bulunmaktadır. Su bir yönüyle ölümü çağrıştırır ve dikey boyutlarda ise yıkıcılığın karşılığıdır. Çünkü efsanede kahraman intikam arzusuyla beklerken karşısına çıkan davet su unsurudur. "Su böylelikle ölmeye davettir; temel maddesel sı̆̆ınaklardan birine kavuşmamızı sağlayan özel bir ölüme davettir. " ${ }^{14}$ Toplumsal hayat, yardımlaşmayı ve paylaşımı olağan gören normları insana zorunlu kılmaktadır. Fakat insanlara sunulan normların dışında eylem sergileyenler toplumsal vicdanda cezalandırılır. Anlatıda yer alan mahalle sakinleri zengin olmalarına rağmen karşıt eylem olan cimrilik özelliğini sergilemektedirler. Mahalle sakinleri bu özelliğe sahip olmalarının yanında kapılarına gelen fakir adamın yardım çağrılarına da yanıt vermemiştir. Söz konusu durum yaşamda kaosun ortaya çıkmasını sağlamıştır. Efsane kahramanının karşısına kendiliğinden çıkan su dengenin sağlanması noktasında işlevselliğini ortaya koymuştur. Mahalle sakinleri zengin olduğundan hiçbir şeye ihtiyaçları olmadığı bilincini yaşamaktadırlar. Fakat birden ortaya çıkan su mahalle sakinlerini kendisine muhtaç ederek bağımlılık oluşturmuştur. Suyun oluşturduğu bağımlılık insanları suyu içmeye yönlendirmiştir. Kahraman tarafindan suyun içine zehir atılarak mahalle sakinlerinin ölümüne davetiye çıkarılmıştır. Çünkü su yaptığ1 özel davetle kendiliğine yabancılaşmış insanları özel alanına çekmiştir.

Ahlat ilçesinde derlenen Husi Baba ${ }^{15}$ efsanesi ilahi kaynaklı olarak ortaya çıkan kutsal sudan bahsetmektedir. Rivayete göre Husi Baba'nın yaşadığı bölgede insanlar hastalanmaya başlar. Bunun üzerine Husi Baba, Allah'a yakarır ve halk için şifa dileğinde bulunur. Gece uykuya dalan evliyaya rüyada ilahi bir çağrıyla insanların ihtiyaç duyduğu suyun yeri söylenir. Kendisine söylenen yere giden Husi Baba uzun aramalardan sonra yerden çıkan suyla karşılaşır. Kendisi de aynı

12 Ramazan, Korkmaz, “Dede Korkut Hikâyelerindeki Su Kültünün Mitik Yorumu” Türk Kültürü, 1998, s. 95.

13 Barış, Kızıltoprak, Bitlis Masal ve Efsaneleri, Bitirme Tezi, Yüzüncü Yıl Üniversitesi, Van, 1998.

14 Gaston, Bachelard, Su ve Düşler (Maddenin İmgelemi Üzerine Deneme), (çev. Olcay Kunal), İstanbul, Yapı Kredi Yayınları, 2006, s. 67.

15 Kaynak kişi, Şükran Güleser, Akyürek, 1954, Lisans Mezunu, Emekli Öğretmen, Ahlat 
hastalığa yakalanan evliya suda yıkandıktan sonra şifa bulur. Günümüzde bile romatizma hastalığı olan insanların çıkan suyla şifaya kavuştuğuna inanılmaktadır. Anlatının başlangıç sorunu insanların hastalıklarla mücadele edemez hale gelmesidir. Hastalıkları karşısında çaresizliği yaşayan insanlar kutsal değerlerin taşıyıcısı olarak gördügü Husi Baba adlı evliyaya başvurur. İnsanların yardım çağrısına kulak veren evliya, üst otoriteden yardım dilemeye başlar. Yücelik algılarımızın en üst noktasından, mitik bir yol olan rüya yoluyla evliyaya hastalıkların ilacı olarak kutsal unsur suyun yeri gösterilir. Efsanede ilahi yollarla gelen kutsal suyun hastalığın çaresi olarak sunulması mitik dönemden gelen inanışın bir sonucu olarak değerlendirilebilir. Arayış sonucunda bulunan suyla evliyanın ve halkın yıkanarak hastalıklarından kurtulması içsel arınma ve temizlenmeye işaret olarak okunması gereken bir diğer noktadır. "O zaman arı sudan ilkin hem etkin hem de tözsel bir arılık istenir. Arınmayla üretken, yenilikçi, birden fazla değer içeren bir güce katılır insan. Bu iç gücün en iyi kanıtı, sıvının her damlasına ait olmasıdır." 16 İlahi kaynaklı olarak gönderilen kutsal su bir yönüyle arı sudur. Arı olan bu sudan istifade eden insanlar sağlıklarına kavuşmuşlardır. Efsanede verilen temel sorun olan hastalık sembolik manada sıradanlaşan ve yaşadığg mekânda bunalan insanların ruh hali olarak okunabilir. Ortaya çıkan su ile yıkanan insanlar içerisinde bulunduğu yerden çıkarak üretkenliği, yeniliği ve farklı değişimleri yakalayarak üzerinde bulunan kirliliklerden arınmışlardır.

Canlı yaşamının devam etmesi için gerekli olan su sahip olduğu bu özelliğiyle tanrının insanlara sunduğu başat nimetlerdendir. Üst otorite olan yaratıcı canlıların hizmetine sunduklarıyla evrendeki işleyişin uyum içerisinde çalışmasını sağlamıştır. Bitlis’ten derlenen taş kesilme efsanelerinin bazılarında su unsuru ilahi kaynaklı olması yönüyle olayların merkezinde yer almaktadır. Gelin Alayı Taşlar ${ }^{17}$ efsanesinde sıcak bir yaz gününde civar köylerden bir diğerine gelin almaya gidilir. Gelin alayı yoldayken sıcaklıktan dolayı herkes su aramaya başlar. İnsanlar su bulamad1ğı için Allah'a yalvarmaya başlar. Suyun çıkması halinde ise adak adayacakları sözünü verirler. Birden bire yerden su fişkırır ve herkes susuzluğunu giderir. Daha sonra ise alayda bulunan bir kişi eline geçen biti öldürür ve onu adak olarak sayar. Bu olaydan dolayı düğün alayı taş kesilir.

Suyun merkezde olduğu efsanelerden birisi de Altınoluk ${ }^{18}$ adlı metindir. Rivayete göre günün birinde dört yolcu yola koyulur. Uzun süre yol gittikten sonra susuzluk yaşamaya başlarlar. Allah'a yakarmaya başlayan dört adam ondan su diler ve eğer istekleri gerçekleşirse kurban keseceklerini söylerler. Çatlamış yerden altın bir oluk çıkar ve su akmaya başlar. Dört adam suyu içtikten sonra verdikleri sözü unutur ve böbürlenmeye başlar. Bunun üzerine bal gibi tatlı olan suyun tadı bozulur ve dört adam taş kesilir.

Bölgenin bilinen önemli efsanelerinden olan Altın Kalbur ${ }^{19}$, susuzluk etrafında gelişen olaylardan bahsetmektedir. Anlatıya göre yıllar önce çoban bir kadın koyunlarını otlatmak için tenha bir yere götürür. Aradan zaman geçtikten sonra çoban ve sürüsü su aramaya başlar. Bütün arayışlara rağmen su bulamayan çoban Allah'a dua etmeye ve su dilemeye başlar. Duasının kabul olması halinde ise diğer metinlerde olduğu gibi adak adama eylemini yerine getireceğini söyler. Eliyle toprağı kazıyan çoban birden yerden çıkan su ile karşılaşır. Hayvanlarıyla birlikte susuzluğunu gideren kadın verdiği sözü yerine getirmek için başından çıkardığı biti öldürür. Yaptığı eylem neticesinde ise koyunlarıyla birlikte taş kesilir. Söz konusu metinlerde en üst otorite olan tanrıya karşı

16 Gaston, Bachelard, Su ve Düşler (Maddenin İmgelemi Üzerine Deneme), (çev. Olcay Kunal), İstanbul, Yapı Kredi Yayınları, 2006, s. 160.

17 Barış, Kızıltoprak, Bitlis Masal ve Efsaneleri, Bitirme Tezi, Yüzüncü Yıl Üniversitesi, Van, 1998.

18 Barış, Kızıltoprak, Bitlis Masal ve Efsaneleri, Bitirme Tezi, Yüzüncü Yıl Üniversitesi, Van, 1998.

19 Kaynak kişi, Fazilet, Alataş, 1934, Okur- Yazar Değil, Ev Hanımı, Bitlis/ Merkez. 
yerine getirilmeyen vaatlerden sonra ortaya çıkan olağanüstü cezalandırma motifinden bahsedilmektedir. Ana sorun anlatıdaki canlıların susuz kalması ve bulundukları yerde suyun olmamasıdır. Su unsuruna kavuşmak için ise kişilerin yöneldiği yer tanrıdır. Kişiler için zaruri gereksinim olan su unsuru tanrısal yollarla ortaya çıkmaktadır. Efsane kahramanları tarafindan edilen dualar ve vaat edilenler neticesinde ortaya çıkan unsur böylelikle kutsallık kazanarak olağanüstü şekilde gereksinimleri karşılamaktadır. Bir bakıma yerden su çıkması kozmogonik eylemin tezahürü olarak karşımıza çıkmaktadır. Sözü geçen efsane metinlerinde Allah'a vaat edilen durumların gerçekleşmemesi sonucunda duayı eden kişiler ve yanında bulunan varlıklar taş kesilmiştir. Kurak ve çorak yerlerde yerden suyun ilahi güçle ortaya çıkması tanrının evreni insanların hizmetine sunmasının prototipi olarak yorumlanabilir. Bu bağlamda su hayatın ve yaşamın karşılığı olan bir imaj olarak verilmiştir. Çünkü toprağın çatlaklarından çıkan su insanlığın ilk yaratılış mitine paralellik gösteren bir durumdur. Tanrı tarafindan insanlara bahşedilen yaşamın karşılığ ise yine tanrı tarafindan koyulan kaideleri yerine getirmektir. Fakat verilen örneklerde efsane kahramanları tanrı tarafindan verilen nimetlere karşılık kendiliklerinden bir şeyler vermekten kaçınmışlardır. Kendiliğinden bazı şeyleri tanrıya sunan birey böylece verilen hayata karşı sadakatini gösterir. Çünkü "Kul böylece, sahip olma, çıkar güdüsüne ilişkin konularda Allah'ın koymuş olduğu diğer bütün değer ölçülerine de uymayı kabul etmiş olmaktadır. " ${ }^{20}$ Olağan yasaları çiğneyen kişiler efsanelerde tanrısal gücün meşru karşılığı olan taşa dönüşme cezasıyla karşı karşıya kalır. Efsanelerde kutsal kaynaklı olarak ortaya çıkan su unsuru cansız olmasına karşın canlı varlıklara hayat vererek onları yaşatmıştır. Ancak yaratıcıya karşı sorumluluğunu yerine getirmeyen bireyler taş kesilerek yaşamdan izole edilmiştir.

Yapısında çeşitli varlıkları barındıran ve besleyen durgun sular dişil özelliğiyle kolektifin bilinçdışında kendisine yer bulmakta ve kültürel ürünlere bu şekilde yansımaktadır. Bitlis durgun sular açısından oldukça zengin bir yapıya sahiptir. Bu bağlamda derlenen metinlerin arasında bulunan göl efsaneleri sembolik değerler taşıması açısından oldukça önemlidir. Bölgede bulunan Van Gölü, Nazik Gölü, Aygır Gölü ve Arin Gölü yüklenen analık ve dişilik özellikleriyle söylencelerin muhtevasında kendisine yer bulmaktadır. Adilcevaz ilçesinde derlenen söz konusu efsaneye göre zamanın birinde Van Gölü ve Aygır Gölü'nün²1 birleştirilmesi gündeme gelir. Projeyi çizen adamın gece rüyasına Aygır Gölü gelir ve adama "Ey İnsanoğlu sen kimsin de beni kızımın ayağına götürüyorsun? Kızımı bana getir beni ona değil" şeklinde uyarıda bulunur. Proje sahibi adam eyleminden vazgeçse de hayat içerisinde başına olumsuz olaylar gelir.

Anlam görünmek ister, mitik düşüncede üretilen anlamın devamı niteliğinde olan efsaneler bu anlamı görüntü düzeyine ulaştırır. Aygır Gölü kapladığı alan açısından Van Gölü’ne oranla oldukça küçüktür. İnsanların bilinçdışında yalnız ve küçük olarak yer edinen göl analık kurumu ile ilişkilendirilmiştir. Su ve Düşler adlı çalışmasında Bachelard "Duygusal olarak doğa annenin yansımasıdır." 22 şeklinde bir tanımlama yapmaktadır. Doğanın önemli unsurlarından olan göller durgunluğu ve yapısında barındırdığı yaşam itibariyle dişil özellik gösterip annelik özelliklerini üzerinde büyük ölçüde taşımaktadır. İnsanoğlu algıları sayesinde hâkimiyet sağladığı unsurlarla daha fazla ilişki geliştirerek o varlığı daha fazla sahiplenmektedir. Kapladığı alan ve konumu bakımından bölge insanının dikkatini çeken Aygır Gölü analık değeriyle toplumsal algıda böylece yer edinmiştir. Aygır Gölü’ne bölgede yüklenen anlam varlığın ana unsuru olan su ile alakalı olarak efsanede yer edinmektedir.

\footnotetext{
20 Abdurrahman, Kasapoğlu, Kuran'da İman Psikolojisi, İstanbul, Yalnız Kurt yayınları, 1997, s. 44.

21 Kaynak Kişi, Adnan, Birol, 1971, İlkokul Mezunu, Baston Ustası.

22 Gaston, Bachelard, Su ve Düşler (Maddenin İmgelemi Üzerine Deneme), (çev. Olcay Kunal), İstanbul, Yap1 Kredi Yayınları, 2006, s. 131.
} 
Türk düşün sisteminde evrende bulunan bütün varlıkların sahip oldukları bir iye bulunmaktır. Bu bağlamda su varlığın ana kaynağı olarak görüldüğ̈nden su iyeleri daha fazla önem kazanmaktadır. Nitekim farklı Türk halklarında su kutsal kabul edilmekte ve unsurun korunması için sosyal normlarla önlem alınmaya çalışılmaktadır. Ahlat ilçesinde derlenen Nazik Gölü²3 efsanesine göre doğumuna az bir süre kalan kadının birinin kocası ortadan kaybolur. Kadın çocuğunu yetim büyütmemek için kocasını aramaya başlar. Bunun için ilk olarak dağlara giderek onlardan yardım ister. Dağ iyesinden istediği yanıtı alamayan kadın çocuğunu doğurur. Kız çocuğu doğurduğu için toplum tarafından dışlanan kadın kendisine sığınmak için alan arar. Kadın, Nazik Gölü'nün kıyısına gelir ellerini açar ve sudan yardım ister. Çağrısından sonra gölün ortasında bir ada oluşur. Kadın çocuğuyla birlikte gölün varlık alanına yerleşir. Düşün sistemi içerisinde yer alan "yer- sub" inancında iyelerin kutsal ve koruyucu olduğu toplumsal bellek içerisinde konumlanmıştır.

Anlatıda kadının kaybolan kocasını arama aşamasında ilk olarak başvurduğu yer dağlardır. Dağlarla canlı bir varlık gibi konuşan ve onlardan yardım isteyen kadın gerekli yanıtı alamadıktan sonra son çare olarak suyun ruhundan yardım dilemiştir. Dağın anlatı içerisinde kadının çağrısına yanıt vermemesi unsurun eril özelliğiyle alakalı olarak okunabilir. Çünkü anlatının sonunda toplumsal alanın dışına çıkarılan kadın son olarak diğer canlıları yapısında besleyen suyun ruhuna seslenmiştir. Dağ ve su iyesinin anlatı içerisinde verilmesinin amacı mitsel düşünenin şekillendirdiği ilk unsur olan suyun önemini daha fazla vurgulamaktadır. Kadının "Erim yok, kızımla ortada kaldım. Balıklara ve atlara bă̆rını açan Ey su, bana da yardım et" şeklinde ettiği dua mitsel dönemin yansıması olarak efsane içerisinde tezahür etmiştir. Kadının doğurduğu çocukla birlikte sahipsiz kalmasından sonra sığındığı ve koruma talep ettiği yer suyun yaşamsal sınırlarıdır. Görünmek isteyen anlam kolektif şuuraltının kendisini dışa vurmasıyla böylece ortaya çıkmıştır. İnsanların arasında kabul görmeyen ve kovulan kadın ana rahmi özlemiyle suyun dişiliğine sığınarak korunmaya çalışmıştır. Kadının canlı bir nesne olarak seslendiği su, kendisine yapılan çağrıyı geri çevirmemiştir.

\section{Sonuç}

Yaşamın ana kaynağı konumunda olan su, etrafında kendine özgü bir yaşam alanı meydana getirir. Yatay boyutta canlıların biyolojik yaşam kaynağı olan su, dikey boyutta inanış ve ritüellerin mitik kaynağı konumundadır. Birey dünyaya gelmeden önce bile anne karnında bir suyun içinde insan suretine bürünür, gelişir ve doğuma hazır hale gelir. Çocuğu olmayan kadınlar, çocuk sahibi olabilmek için şifalı olduğuna inanılan sular ile yıkanır. Kırkı çıkan kadın ve bebek kırk çıkarma ritüelinde su ile arınır. İslamiyet'te ölen insanlar yıkanmadan defnedilmez. Çünkü insan bu hayata temiz gelmiştir ve temiz bir şekilde de defnedilir.

Bitlis efsanelerinde su kültünün farklı şekillerde yansımalarını görmek mümkündür. Efsanelerde su kaynaklarının korunması için suyun etrafinda oluşan efsaneler, hem yaşam kaynağının korunmasını hem de insanların şifa bulmasını sağlayan bellek mekânlarını oluşturur. Bitlis’te anlatılan efsaneler yoluyla su kaynaklarının korunması yolunda halkın bilinçaltına kodlar yüklenir.

Seydo Bulağı ve Husi Baba efsanelerinde şifalı olduğuna inanılan su rüyalar yoluyla haber verilir. İlahi bir kudretle rüyalar yoluyla halkın şifa bulacağı su Husi Babaya iletilir. Husi Baba bu su kaynağını halka söyler ve halk şifa bulur. İnanışa göre günümüzde de yöre insanı fiziksel rahatsızlıklarından kurtulmak için bu kaynağa gelmektedir. Efsaneler insanın bilinçaltına tesir ederek onların psikolojik anlamda rahatlamasını sağlar. Aynı bakımdan Seydo Bulağı efsanesinde de su gizil güçleri harekete geçiren bir unsur olarak dikkati çeker. Seydo'nun bitkiyi koparması sonu- 
cunda ortaya çıkan su, Bitlis’te ortaya çıkan bu su kaynağı etrafında oluşan anlam evreninin ana kaynağıdır.

Aygır Gölü efsanesinde de su karşımıza anne arketipinin bir yansıması olarak karşımıza çıkmaktadır. Efsaneye göre Aygır Gölü ve Van Gölü birleştirilmek istenir. Mühendisin rüyasına giren Van Gölü ben kızımın değil, kızım benim ayağıma gelmeli der. Dikey boyutta anne arketipini yansitan efsane, yatay boyutta ise değerler eğitimine dair göndergelere sahiptir. Kültürümüzde büyükler küçüklerin ayağına gitmez. Bu durum efsane aracılığıyla kültürel belleğe işlenir.

Sonuç olarak Bitlis’teki efsaneler üstelendiği sembolik değerlerle, anne sembolizmi, şifa ve arındırıcılık, hayat verici olma, gizil güçlerin kaynağı gibi unsurlara sahiptir. Bu da su kültü inancının efsanelerde çeşitli inanış ve ritüellerle devam ettiğini gösterir. Günümüzde varlığını devam ettiren su kaynaklarına yörede su kültünün bir yansıması olarak sayg1 gösterilmekte, korunmakta ve şifa bulmak amacıyla gidilmektedir.

\section{Kaynakça}

Alizade, Rövşen, Türk Kültüründe Kültler, İstanbul, İstanbul Aydın Üniversitesi Yayınları, 2012

Asena, G. Ahmet Can. Altay Bilik, İstanbul, Pan Yayıncılık, 2011.

Bachelard, Gaston. Su ve Düşler (Maddenin İmgelemi Üzerine Deneme), (çev. Olcay Kunal), İstanbul, Yapı Kredi Yayınları, 2006.

Bayat, Fuzuli. Türk Mitolojik Sistemi II (Kutsal Dişi- Mitolojik Ana - İyeler ve Demonoloji), Ankara, Ötüken Yayınları, 2016.

Elıade, Mircea. Okültizm, Büyücülük ve Kültürel Modalar, (çev. Cem Soydemir), Ankara, Doğu Batı Yayınları, 2016.

Kasapoğlu, Abdurrahman. Kuran’da İman Psikolojisi, İstanbul, Yalnız Kurt yayınları, 1997.

Kızıltoprak, Barış. Bitlis Masal ve Efsaneleri, Bitirme Tezi, Yüzüncü Yıl Üniversitesi, Van, 1998.

Korkmaz, Ramazan. "Dede Korkut Hikâyelerindeki Su Kültünün Mitik Yorumu” Türk Kültürü, 1998.

\section{Kaynak Kişiler}

K. K. 1. Akyürek, Şükran Güleser, 1954, Lisans Mezunu, Emekli Öğretmen, Ahlat

K. K. 2. Alataş, Fazilet, 1934, Okur- Yazar Değil, Ev Hanımı, Bitlis/ Merkez.

K. K. 3. Birol, Adnan, 1971, İlkokul Mezunu, Baston Ustası.

K. K. 4. Göktürk, Ceylan, 1992, Lise Mezunu, Ev Hanımı, Ahlat. 